\title{
ANALISIS PERLAKUAN AKUNTANSI TERHADAP PELEPASAN DAN PENGHENTIAN ASET TETAP PADA PT. $X$
}

\author{
Elshinta Toisuta ${ }^{1}$, Lintje Kalangi $^{2}$, Sonny Pangerapan ${ }^{3}$ \\ ${ }^{1,2,3}$ Jurusan Akuntansi, Fakultas Ekonomi dan Bisnis, Universitas Sam Ratulangi, Jl. Kampus Bahu, Manado, \\ 95115, Indonesia \\ E-mail : elshintatoisuta@gmail.com
}

\begin{abstract}
The disposal and termination of fixed assets in an entity can be carried out in various ways, like disposing, selling, and exchanging. The fixed assets are released and discontinued because of damage or fixed assets have been expired so that they no longer provide economic benefits to the company. The accounting treatment for the disposal and termination of fixed assets is seen in terms of recognition, measurement and presentation. This study aims to determine whether the accounting treatment of the disposal and termination of fixed assets is in accordance with PSAK No. 16. The research method used is descriptive method. The collected data and information are in accordance with the facts and actual condition that occur within company. The results show that the accounting treatment of the disposal and termination of fixed assets in terms of recognition and presentation is in accordance with PSAK No. 16. While in terms of measurement, it is still not in accordance with PSAK No. 16. Keywords: Disposal and Termination, Accounting Treatment, Fixed Assets
\end{abstract}

\section{PENDAHULUAN}

Aset tetap yang dimiliki oleh badan usaha tidak dapat digunakan secara terus menerus karena aset tetap mempunyai batas kegunaan hingga suatu saat tidak berfungsi lagi. PSAK 16 (paragraf 67) revisi 2016 menyatakan, jumlah tercatat aset tetap dihentikan pengakuannya: (a) Pada saat pelepasan; atau (b) Ketika tidak terdapat lagi manfaat ekonomi masa depan yang diharapkan dari penggunaan dan pelepasannya.

Aset tetap yang tidak lagi berguna dapat dihentikan, dijual, atau dipertukarkan dengan aset tetap lainnya. Keuntungan atau kerugian yang timbul dari penghentian pengakuan aset tetap ditentukan sebesar selisih antara jumlah hasil pelepasan neto (jika ada), dan jumlah tercatatnya, dan dimasukan dalam laba rugi. Tujuan akuntansi terhadap pemberhentian aset tetap adalah agar rekening-rekening yang berhubungan dengan aset tetap dapat menyajikan informasi mengenai perolehan harga aset tetap, akumulasi penyusutan aset tetap dan nilai buku aset tetap, secara layak.

Aset tetap yang digunakan dalam kegiatan operasional PT. X tidak terlepas dari kemungkinan terjadinya pelepasan dan penghentian yang diakibatkan kondisi fisik aset tidak memungkinkan untuk dioperasikan atau rusak. Dikarenakan aset tetap merupakan unsur yang penting, maka dalam proses pelepasan dan penghentian aset tetap diperlukan perhatian khusus. Proses pelepasan dan penghentian aset tetap harus dilakukan dengan prosedur dan langkah-langkah yang benar dan tepat. Selain itu dalam proses pelepasan dan penghentian aset tetap juga perlu diperhatikan bagaimana perlakuan akuntansi yang diperlukan pada saat terjadi pelepasan dan penghentian aset tetap Hal ini dikarenakan di dalam laporan keuangan aset tetap memiliki nilai yang cukup besar dan akan mempengaruhi pengambilan keputusan oleh pihak perusahaan. 


\section{TINJAUAN PUSTAKA}

Konsep Akuntansi. Pada umumnya, akuntansi dapat diartikan sebagai sebuah sistem informasi yang menyajikan laporan kepada para pengguna informasi akuntansi atau kepada pihak-pihak yang mempunyai kepentingan (stakeholders) atas hasil kinerja dan kondisi keuangan perusahaan (Hery, 2015:6).

Akuntansi Keuangan. Akuntansi keuangan merupakan salah satu bidang ilmu akuntansi yang mempelajari tahapan dancara untuk membuat dan menghasilkan laporan keuangan yang berguna untuk berbagai pihak baik dari dalam maupun dari luarperusahaan (Sujarweni, 2015:1).

Laporan Keuangan. Laporan keuangan adalah suatu informasi keuangan tentang entitas pelapor yang berguna bagi investor dan kreditor, baik yang telah ada maupun yang berpotensi dalam mengambil keputusan dalam kapasitas mereka sebagai penyedia modal (Kieso et al, 2014:7).

Aset Tetap. Aset tetap adalah aset yang dimiliki dan digunakan perusahaan yang jangka waktunya lebih dari satu tahun dan mempunyai masa manfaat yang mempunyai nilai susut atau nilai kegunaan semakin lama semakin berkurang (Lubis, 2017:29).

\section{Perlakuan Akuntansi Aset Tetap}

Pengakuan Aset Tetap. PSAK No.16 paragraf 07 menyatakan bahwa aset tetap harus diakui jika dan hanya jika (paragaraf 7) besar kemungkinan manfaat ekonomis yang berhubungan dengan aset tersebut akan mengalir ke perusahaan dan biaya perolehan aset dapat diukur secara andal.

Pengukuran dan Penilaian Aset Tetap. Suatu aset tetap yang memenuhi kualifikasi diakui sebagai aset tetap pada awalnya harus diukur sebesar biaya perolehan. Adapun komponenkomponen yang termasuk sebagai unsur biaya perolehan sebuah aset tetap menurut PSAK 16 adalah (Pontoh, 2013) :

1. Harga perolehannya, termasuk bea impor dan pajak pembelian yang tidak dapat dikreditkan setelah dikurangi diskon pembelian dan potongan lain.

2. Setiap biaya yang dapat diatribusikan secara langsung untuk membawa aset ke lokasi dan kondisi yang diinginkan supaya aset tersebut siap digunakan sesuai dengan maksud manajemen.

Penyusutan Aset Tetap. Setiap aset yang digunakan oleh perusahaan apabila digunakan secara terus menerus akan mengalami penurunan nilai, hal ini nenyebabkan masa manfaat dan nilai guna aset semakin berkurang dari waktu kewaktu. Hal inilah yang menyebabkan adanya penyusutan pada setiap aset tetap kecuali tanah.

Penghentian Pengakuan dan Pelepasan Aset Tetap. PSAK 16 (paragraf 67) revisi 2016 menyatakan jumlah tercatat aset tetap dihentikan pengakuannya: (a) Pada saat pelepasan; atau (b) ketika tidak terdapat lagi manfaat eknomik masa depan yang diharapkan dari penggunaan dan pelepasannya. Sehingga, apabila sebuah aset tetap dipertimbangkan tidak lagi memberikan manfaat ekonomi atau mengalami kerusakan, maka aset tetap tersebut dapat dihentikan (baik dalam atau sesudah umur manfaat), dijual kepada pihak lain, disewakan atau ditukar dengan aset baru, baik aset sejenis maupun tidak.

\section{METODE PENELITIAN}

Jenis Penelitian. Jenis penelitian yang digunakan dalam penelitian ini adalah jenis penelitian kualitatif. Hal ini dikarenakan peneliti melakukan penelitian dengan cara terlibat langsung dengan objek penelitian untuk memperoleh data dan informasi yang diperlukan mengenai perlakuan akuntansi terhadap pelepasan dan penghentian aset tetap yang diterapkan dalam PT. X. 
Tempat dan Waktu Penelitian. Tempat penelitian dilakukan pada PT. X, yang beralamat di jalan A. M. Sangaji Km 12, Kota Sorong, Papua Barat, dengan waktu penelitian dimulai sejak bulan Mei 2018 sampai dengan selesai.

\section{Metode Pengumpulan data}

Jenis data. Dalam penelitian ada dua jenis data yang digunakan yaitu data kualitatif berupa hasil wawancara mengenai perlakuan akuntansi terhadap pelepasan dan penghentian aset tetap dan data kuantitatif berupa laporan keuangan perusahaan.

Sumber data. Sumber data yang digunakan dalam penelitian ini adalah data primer. Adapun yang menjadi sumber data berupa hasil wawancara dan dokumentasi yang dilakukan secara langsung kepada Kepala Bidang Administrasi dan Keuangan PT. X terkait dengan data-data yang diperlukan dalam penelitian.

\section{Metode pengumpulan data}

1. Wawancara. Wawancara dilakukan kepada Kepala Bidang Administrasi dan Keuangan PT. X. Adapun pertanyaan yang akan ditanyakan pada saat wawancara adalah:

a. Bagaimana kebijakan akuntansi mengenai aset tetap pada PT. X?

b. Bagaimana perlakuan akuntansi atas aset tetap yang dihentikan dan dilepaskan pada PT. X?

c. Faktor-faktor apa saja yang menjadi pertimbangan PT. X melakukan pelepasan dan penghentian aset tetap?

2. Dokumentasi. Dokumentasi dilakukan dengan mengumpulkan dokumen-dokumen yang diperlukan dalam proses penelitian pada PT. X seperti:

a. Laporan keuangan dalam hal ini neraca PT. X tahun 2015-2016.

b. Laporan daftar aset tetap PT. X tahun 2015-2016.

Metode dan Proses Analisis. Metode analisis data yang digunakan dalam penelitian ini adalah metode analisis deskriptif, yaitu menjelaskan perlakuan akuntansi dan pencatatan dalam laporan keuangan terhadap pelepasan dan penghentian aset tetap pada PT. X. Datadata yang diperlukan dalam penelitian ini berasal dari hasil wawancara dan dokumentasi.

\section{HASIL PENELITIAN DAN PEMBAHASAN}

\subsection{Hasil Penelitian}

Kebijakan Akuntansi Aset Tetap Pada PT. X. Berdasarkan hasil penelitian, kebijakan akuntansi aset tetap yang berlaku pada PT. X merupakan prinsip yang digunakan sebagai acuan dalam pengelolaan aset tetap. Kebijakan akuntansi aset tetappada PT. X meliputi: (1) pengakuan biaya perolehan aset tetap, (2) metode penyusutan yang digunakan, (3) beban pemeliharaan dan perbaikan aset tetap, dan (4) pelepasan dan penghentian aset tetap. Penggolongan dan presentase penyusutan aset tetap pada PT. X adalah sebagai berikut:

Tabel 1. Penggolongan dan Presentase Penyusutan Aset Tetap PT. X

\begin{tabular}{lrc}
\hline \multicolumn{1}{c}{ Jenis Aset Tetap } & Total Harga Perolehan & Penyusutan per Tahun \\
\hline Tanah & $3.949 .650 .000,00$ & - \\
Bangunan & $1.921 .057 .010,00$ & $10 \%$ \\
Mesin dan Peralatan & $43.740 .513 .700,00$ & $20 \%$ \\
Kendaraan & $21.117 .982 .721,00$ & $20 \%$ \\
Inventaris Kantor & $767.186 .383,00$ & $20 \%$ \\
\hline
\end{tabular}




\section{Pelepasan dan Penghentian Aset Tetap pada PT. X}

Pelepasan dan penghentian dengan cara dijual. Perusahaan mencatat transaksi atas pelepasan dan penghentian aset tetap yang dijual dengan membuat ayat jurnal sebagai berikut:

Kas

XXX

\section{Penjualan Aset Tetap $\quad$ xxx}

Pelepasan dan penghentian dengan cara dibuang. Perusahaan mencatat transaksi atas pelepasan dan penghentian aset tetap yang dijual dengan membuat ayat jurnal sebagai berikut:

a. Jurnal umum yang digunakan dalam pelepasan dan penghentian aset tetap dengan cara dihentikan jika aset tetap tersebut telah habis disusutkan:
Akumulasi penyusutan- Aset Tetap
XXX
Aset Tetap
$\mathrm{xxx}$

b. Jurnal umum yang digunakan dalam pelepasan dan penghentian aset tetap dengan cara dihentikan jika aset tetap tersebut belum habis disusutkan:
Akumulasi penyusutan- peralatan
$\mathrm{xxx}$
Rugi atas penghapusan aset tetap
$\mathrm{XXX}$
Aset Tetap
XXX

\section{Perlakuan Akuntansi terhadap Pelepasan dan Penghentian Aset Tetap pada PT. X}

1. Perlakuan akuntansi terhadap pelepasan dan penghentian aset tetap dengan cara dijual.

Pengakuan. Aset tetap yang dilepaskan dan dihentikan dengan cara dijual oleh PT. X dihentikan pengakuannya dengan menghapus nilai aset tetap tersebut sebesar nilai bukunya yang tercatat di dalam neraca.

Pengukuran. Pengukuran saat pelepasan dan penghentian aset tetap dengan cara dijual pada PT. X untuk mengukur laba atau rugi yang dihasilkan dari pelepasan dan penghentian aset tetap yang diukur sebesar selisih antara jumlah hasil pelepasan neto, jika ada, dengan jumlah tercatatnya.

Penyajian. Hasil laba atau rugi yang timbul akibat dari pelepasan dan penghentian aset tetap dengan cara dijual disajikan di dalam laporan laba rugi dan diakui sebagai pendapatan dan beban lain-lain.

Berdasarkan hasil penelitian diketahui pada tahun 2016 dilaporkan bahwa terdapat satu unit Truck Fuso FM 517 HS yang mengalami kecelakaan saat digunakan dalam kegiatan proyek, yang mengakibatkan fungsi dari aset tersebut kurang berjalan dengan baik. Akibat dari peristiwa tersebut PT. X memutuskan untuk melepaskan Truck Fuso FM 517 HS dengan cara dijual pada tanggal 1 Oktober dengan harga sebesar Rp350.000.000,00. PT. X mencatat transaksi tersebut dengan membuat jurnal sebagai berikut:

Kas 350.000 .000

$$
\text { Penjualan Aset Tetap } \quad 350.000 .000
$$

Tabel 2. Perhitungan PenyusutanPT. X untuk Aset Tetap yang dijual Tahun 2016

\begin{tabular}{lcccccc}
\hline Jenis Aset & Harga & \multicolumn{3}{c}{ Beban Penyusutan } & Akumulasi & Nilai Buku \\
\cline { 3 - 5 } Tetap & Perolehan & Thn 2014 & Thn 2015 & Thn 2016 & Penyusutan & 2016 \\
\hline Truck & 665.000 .000 & 133.000 .000 & 133.000 .000 & 133.000 .000 & 399.000 .000 & 266.000 .000 \\
Fuso FM & & & & & & \\
517 HS & & & & & & \\
\hline
\end{tabular}

Dari perhitungan penyusutan diatas diperoleh nilai buku pada tahun 2016 untuk aset tetap jenis kendaraan Truck Fuso FM 517 HS sebesar Rp266.000.000,00, maka hasil dari pelepasan aset tetap Truck Fuso FM 517 HS yang dicatat dan diakui sebagai laba oleh PT. X sebesar Rp84.000.000,00. 
2. Perlakuan akuntansi terhadap pelepasan dan penghentian aset tetap dengan cara dihentikan.

Pengakuan. Aset tetap yang dilepaskan dan dihentikan dengan cara dihentikan oleh PT. X dihentikan pengakuannya dengan menghapus nilai aset tetap tersebut sebesar nilai bukunya yang tercatat di dalam neraca.

Pengukuran. Pengukuran saat pelepasan dan penghentian aset tetap dengan cara dihentikan pada PT. X dilihat dari apakah aset tetap yang dihentikan sudah disusutkan sepenuhnya, jika aset tetap yang dihentikan belum disusutkan sepenuhnya maka diperlukan pengukuran rugi yang timbul akibat dari pelepasan dan penghentian aset tetap tersebut.

Penyajian. Hasil berupa kerugian yang timbul dari pelepasan dan penghentian aset tetap dengan cara dihentikan oleh PT. X diakibatkan aset tetap yang dihentikan belum disusutkan sepenuhnya sehingga hasil tersebut disajikan di dalam laporan laba rugi dan diakui sebagai beban lain-lain.

Berdasarkan hasil penelitian diketahui bahwa pada akhir tahun 2016 PT. X memutuskan untuk melakukan pelepasan dan penghentian aset tetap berupa mesin Genset Patria PL 125 dengan cara dihentikan. Hal ini dikarenakan aset tetap berupa mesin Genset Partia PL 125 yang dibeli oleh PT. X pada tahun 2000 dengan harga perolehan sebesar Rp475.250.000,00 sudah tidak dapat digunakan lagi dalam kegiatan operasional, diakibatkan keadaan dari aset tersebut yang sudah tidak dapat berfungsi dan tidak dapat diperbaiki lagi. Perusahaan mencatat aset tetap yang sudah habis masa manfaat sebagai berikut:

Tabel 3. Penyajian Aset Tetap yang sudah habis Masa Manfaat

\begin{tabular}{|c|c|c|c|c|}
\hline $\begin{array}{l}\text { Jenis Aset } \\
\text { Tetap }\end{array}$ & Harga Perolehan & $\begin{array}{c}\text { Beban Penyusutan } \\
\text { per } 2016\end{array}$ & $\begin{array}{c}\text { Akumulasi } \\
\text { Penyusutan per } \\
2016\end{array}$ & $\begin{array}{c}\text { Nilai Buku per } \\
2016\end{array}$ \\
\hline $\begin{array}{ll}\text { Genset } & \text { Patria } \\
\text { PL 125 } & \\
\end{array}$ & 475.250 .000 & 0 & 475.250 .000 & 0 \\
\hline
\end{tabular}

Sehingga perusahaan mencatat pelepasan dan penghentian aset tetap berupa mesin Genset Patria PL 125 dengan membuat jurnal seperti berikut:

$$
\text { Akumulasi Penyusutan-Aset Tetap } \quad 475.250 .000
$$

$$
\text { Aset Tetap } \quad 475.250 .000
$$

\subsection{Pembahasan}

Analisis Perlakuan Akuntansi terhadap Pelepasan dan Penghentian Aset Tetap pada PT. X dengan cara Dijual. Berikut ini merupakan Perlakuan Akuntansi atas Pelepasan dan Penghentian Aset Tetap pada PT. X dengan cara Dijual berdasarkan PSAK No 16. 
Tabel 4. Perbandingan Perlakuan Akuntansi atas Pelepasan dan Penghentian Aset Tetap PT. $\mathrm{X}$ dengan PSAK No. 16

\begin{tabular}{|c|c|c|}
\hline PSAK No. 16 & PT. X & Keterangan \\
\hline $\begin{array}{l}\text { 1. Pengakuan } \\
\text { Jumlah tercatat aset tetap } \\
\text { dihentikan pengakuannya pada } \\
\text { saat: } \\
\text { a. Pelepasan } \\
\text { b. ketika tidak terdapat lagi } \\
\text { manfaat ekonomik masa } \\
\text { depan yang diharapkan } \\
\text { dari penggunaan atau } \\
\text { pelepasannya. }\end{array}$ & $\begin{array}{l}\text { Aset tetap yang dihentikan } \\
\text { pengakuannya pada saat aset tetap } \\
\text { tersebut dilepaskan dan ketika aset } \\
\text { tetap tersebut sudah tidak memiliki } \\
\text { manfaat dan kegunaan atau rusak. }\end{array}$ & Sesuai \\
\hline $\begin{array}{l}\text { 2. Pengukuran } \\
\text { Keuntungan atau kerugian yan } \\
\text { timbul dari penghentian pengakua } \\
\text { aset tetap ditentukan sebesar selisi } \\
\text { antara jumlah hasil pelepasan netr } \\
\text { jika ada, dan jumlah tercatatnya. }\end{array}$ & $\begin{array}{l}\text { Perusahaan dalam pengukuran laba } \\
\text { atau rugi yang dihasilkan dari } \\
\text { pelepasan dan penghentian aset tetap } \\
\text { pada belum dilakukan secara baik } \\
\text { sesuai dengan PSAK No. } 16 \text {. }\end{array}$ & Belum Sesuai \\
\hline $\begin{array}{l}\text { 3. Penyajian } \\
\text { Keuntungan atau kerugian yang } \\
\text { timbul dari penghentian pengakuan } \\
\text { aset tetap dimasukan dalam laba } \\
\text { rugi ketika aset tetap tersebut } \\
\text { dihentikan pengakuannya. }\end{array}$ & $\begin{array}{l}\text { Perusahaan mencatat laba atau rugi } \\
\text { yang dihasilkan dari pelepasan dan } \\
\text { penghentian aset tetap pada PT. X } \\
\text { dan menyajikannya di dalam laporan } \\
\text { laba rugi. }\end{array}$ & Sesuai \\
\hline
\end{tabular}

Dalam perlakuan akuntansi mengenai pengukuran laba atau rugi yang dihasilkan dari pelepasan dan penghentian aset tetap oleh PT. X belum dilakukan secara baik. Hal ini dikarenakan untuk aset tetap berupa Truck Fuso FM 517 HS yang dilepaskan dengan cara dijual pada tanggal 1 oktober 2016 seharusnya perusahaan tidak menghitung beban penyusutan pada tahun 2016 sebesar Rp133.000.000,00 karena aset yang dilepaskan belum disusutkan secara penuh pada tahun 2016.

Tabel 5. Perhitungan Penyusutan Aset Tetap yang Dijual oleh PT. X

\begin{tabular}{lcrrrrr}
\hline Jenis Aset & Harga & \multicolumn{3}{c}{ Beban Penyusutan } & Akumulasi & Nilai Buku \\
\cline { 4 - 5 } \multicolumn{1}{c}{ Tetap } & Perolehan & Thn 2014 & Thn 2015 & Thn 2016 & Penyusutan & 2016 \\
\hline Truck & 665.000 .000 & 133.000 .000 & 133.000 .000 & 133.000 .000 & 399.000 .000 & 266.000 .000 \\
Fuso FM & & & & & & \\
517 HS & & & & & & \\
\hline
\end{tabular}

Oleh sebab itu perhitungan penyusutan yang benar adalah sebagai berikut:

Tabel 6. Perhitungan Penyusutan yang benar

\begin{tabular}{lcccccc}
\hline Jenis & Harga & \multicolumn{3}{c}{ Beban Penyusutan } & Akumulasi & Nilai Buku \\
\cline { 3 - 5 } $\begin{array}{c}\text { Aset } \\
\text { Tetap }\end{array}$ & Perolehan & Thn 2014 & Thn 2015 & Thn 2016 & Penyusutan & 2016 \\
\hline $\begin{array}{l}\text { Truck } \\
\text { FusoFM }\end{array}$ & 665.000 .000 & 133.000 .000 & 133.000 .000 & 99.750 .000 & 365.750 .000 & 299.250 .000 \\
517 HS & & & & & & \\
\hline
\end{tabular}

Beban penyusutan pada tahun 2016 sebesar Rp99.750.000,00 dihasilkan dengan menghitung beban penyusutan per 9 bulan [(133.000.000:12) x 9 bulan]. Sehingga dibutuhkan adanya jurnal koreksi atas penjualanaset tetap Truck Fuso FM517 HS sebagai berikut:

a. Jurnal koreksi pertama yang harus dibuat oleh PT. X adalah: 


Akumulasi penyusutan
Beban penyusutan

Beban penyusutan

33.250 .000

Jurnal koreksi pertama dibuat untuk menghapus beban penyusutan per tiga bulan yang terhitung mulai dari Oktober sampai Desember sebesar Rp33.250.000,00.

b. Jurnal koreksi kedua yang harus dibuat oleh PT. X adalah:
Penjualan Aset Tetap
350.000 .000
Akumulasi penyusutan
365.750 .000
Aset Tetap
665.000 .000
Laba Penjualan Aset Tetap
50.750 .000

Jurnal koreksi kedua dibuat untuk mengakui bahwa laba atas pelepasan aset tetap berupa Truck Fuso FM 517 HS yang awalnya diakui oleh PT. X sebesar Rp84.000.000,00 seharusnya diakui hanya sebesar Rp50.750.000,00.Akibat daripencatatan perusahaan yang mengakui laba hasil dari pelepasan aset tetap lebih besar dari yang seharusnya adalah: (1) Nilai buku aset tetap Truck Fuso FM 517 HSyang dicatat oleh PT. X terlalu kecil, (2) Akumulasi penyusutan yang dihitung oleh PT. X terlalu besar, dan (3) Laba atas pelepasan aset tetap yang diakui oleh PT. X terlalu besar.

Analisis Perlakuan Akuntansi terhadap Pelepasan dan Penghentian Aset Tetap pada PT. X dengan Cara Dihentikan. Berikut ini merupakan Perlakuan Akuntansi atas Pelepasan dan Penghentian Aset Tetap pada PT. X dengan cara Dihentikan berdasarkan PSAK No 16.

Tabel 7. Perbandingan Perlakuan Akuntansi atas Pelepasan dan Penghentian Aset Tetap PT. $X$ dengan PSAK No. 16

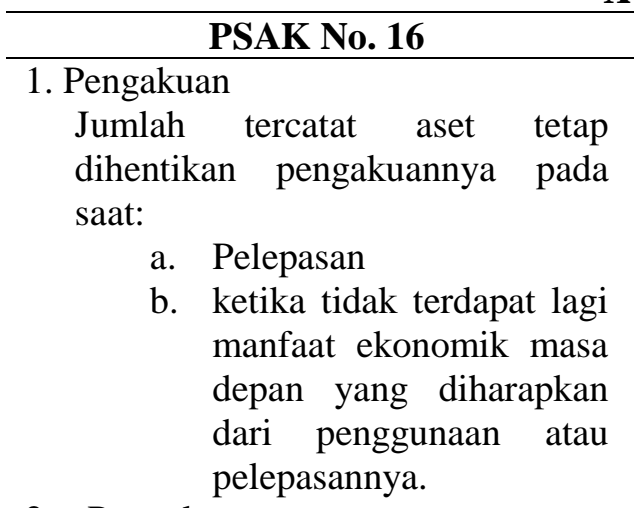

2. Pengukuran

Dalam pengukuran aset tetap yang

Sesuai Keuntungan atau kerugian yan dilepaskan dengan cara dihentikan, timbul dari penghentian pengakua perusahaan mengukur apakah aset aset tetap ditentukan sebesar selisi tersebut sudah disusutkan antara jumlah hasil pelepasan netı sepenuhnya, jika aset tetap yang jika ada, dan jumlah tercatatnya. dihentikan belum disusutkan sepenuhnya maka diperlukan pengukuran rugi yang timbul akibat dari pelepasan dan penghentian aset tetap tersebut.

3. Penyajian Perusahaan mencatat rugi yang dihasilkan dari pelepasan dan Keuntungan atau kerugian yang penghentian aset tetap pada PT. X timbul dari penghentian dan menyajikannya di dalam pengakuan aset tetap dimasukan laporan laba rugi. Keterangan Sesuai $\begin{array}{llr}\text { Aset tetap yang } & \text { dihentikan } \\ \text { pengakuannya } & \text { oleh } & \text { perusahaan }\end{array}$ pada saat aset tetap tersebut tersebut sudah tidak memiliki manfaat dan kegunaan atau rusak. dalam laba rugi ketika aset tetap tersebut dihentikan pengakuannya. 


\section{KESIMPULAN DAN SARAN}

\subsection{Kesimpulan}

Berdasarkan hasil dari pengumpulan dan analisis data yang telah dilaksanakan, maka dapat ditarik kesimpulan sebagai berikut:

1. Kebijakan akuntansi atas aset tetap yang diterapkan perusahaan mulai dari pengakuan biaya perolehan, metode penyusutan yang digunakan, beban pemeliharaan dan perbaikan secara keseluruhan sudah sesuai dengan PSAK No. 16.

2. Perlakuan akuntansi terhadap pelepasan dan penghentian aset tetap dengan cara dijual dilihat dari sisi pengakuan, dan penyajiannya sudah sesuai dengan PSAK No. 16, namun dalam hal pengukuran laba dan rugi atas pelepasan aset tetap yang dilakukan oleh perusahaan masih belum sesuai dengan PSAK No. 16.

3. Perlakuan akuntansi terhadap pelepasan dan penghentian aset tetap dengan cara dibuang baik dilihat dari sisi pengakuan, pengukuran, dan penyajiannya sudah sesuai dengan PSAK No. 16.

\subsection{Saran}

1. Kebijakan perusahaan atas aset tetap dan perlakuan akuntansi terhadap pelepasan dan penghentian aset tetap yang diterapkan perusahaan yang sudah sesuai dengan PSAK No. 16 tetap dipertahankan agar laporan keuangan perusahaan tetap disajikan secara akurat dan bisa memiliki kesamaan/keseragaman secara umum dengan perusahaan lainnya yang sudah menerapkan kebijakan akuntansi yang sesuai dalam laporan keuangannya.

2. Pihak perusahaan lebih memperhatikan dalam hal pencatatan setiap transaksi yang terjadi pada saat pelepasan dan penghentian aset tetap karena hal tersebut berpengaruh terhadap pengakuan laba dan rugi yang akan dilaporkan dalam laporan keuangan perusahaan.

\section{DAFTAR PUSTAKA}

Binh, Pham Duc. 2014. Tangible Fixed Assets Accounting System for Enterprise in Vietnam. International Journal of Economics and Finance University of Hai Duong, Hai Duong, Vietnam. 6(6): 30-37.

Bushymska, K. 2017. The Factor Amalysis on the Efficiency of use of the Fixed Assets of Enterprises. Biznez Inform Ukraine 5(472): 90-96.

Danute Zinkeviciene,Dr. 2010. Factor Affecting The Choice OF Tangible Fixed Asset Accounting Methods: Theoretical Approach.

Effendi, Rizal. 2014. Accounting Principles. Edisi Revisi. Penerbit: Raja Grafindo Persada. Jakarta.

Ernawati. 2014. Analisis Penerapan Standar Akuntansi Keuangan (PSAK No. 16) atas Aset Tetap pada PT. Pelayaran Liba Marindo Tanjungpinang. Skripsi. Universitas Maritim Raja Ali Haji. Tanjungpinang.

Giri, E. F. 2014. Akuntansi Keuangan Menengah 1 Prespektif IFRS. Edisi 1. Cetakan Kedua. Penerbit: UPP STIM YKPN. Yogyakarta.

Gunawan, F. 2015. Perlakuan Akuntansi Aset Tetap Berdasarkan PSAK No. 16 pada Glory Futsal Sukowono. Skripsi. Universitas Muhammadiah Jember. Jember.

Hery. 2015. Pengantar Akuntansi Comprehensive Edition. Penerbit: PT Gramedia Widiasarana. Jakarta.

Hervina, A. 2012. Evaluasi perlakuan akuntansi aktiva tetap pada UMKM Di Wilayah Depok. Skripsi. Universitas Gunadarma. Depok 
Ikatan Akuntansi Indonesia. 2016. Pernyataan Standar Akuntansi Keuangan No. 16 Aset Tetap. Penerbit: DSAK-IAI. Jakarta.

Ismawati. 2017. Analisis perlakuan akuntansi aset tetap pada BPJS Ketenagakerjaan Cabang Kota Tanjungpinang. Skripsi. Universitas Maritim Raja Ali Haji. Tanjung Pinang.

Juan,N. E dan Wahyuni, E. T. 2012. Buku Panduan Praktis Standar Akuntansi Keuangan. Edisi 2. Penerbit: Salemba Empat. Jakarta.

Kartikahadi, H., Sinaga, R.U, dan Syamsul, M. 2016. Akuntansi Keuangan Berdasarkan SAK Berbasis IFRS. Edisi Kedua. Vol. 1. Penerbit: Ikatan Akuntansi Indonesia. Jakarta.

Kieso, D. E., J.J. Weygant, dan T.D. Warfield. 2014. Intermediate Accounting IFRS Edition. 2nd ed. JOHN WOLEY. USA.

Koapaha, V. D. 2014. Evaluasi Penerapan Perlakuan Akuntansi Aktiva Tetap Berdasarkan PSAK No.16 pada RSUP Prof. Dr.R.D. Kandou Manado. Skripsi. Universitas Sam Ratulangi (UNSRAT). Manado.

Lubis, R. H. 2017. Pengantar Akuntansi Jasa. Penerbit: Gava Media. Yogyakarta.

Pontoh, W. 2013. Akuntansi Konsep dan Aplikasi. Penerbit: Halaman Moeka. Jakarta.

Sujarweni, V. W. 2015. Sistem Akuntansi. Cetakan Pertama. Penerbit: Pustaka Baru Press. Yogyakarta. 